\title{
Validation of a Novel and Sensitive RP-HPLC Method for Simultaneous Determination of Cefixime Trihydrate and Sodium Benzoate in Powder for Oral Suspension Dosage Form
}

\author{
MEM Hassouna ${ }^{1 *}$, MM Abdelrahman ${ }^{2}$ and MA Mohamed ${ }^{3}$ \\ ${ }^{1}$ Department of Chemistry, Faculty of Science, Beni-Suef University, Egypt \\ ${ }^{2}$ Department of Analytical Chemistry, Faculty of Pharmacy, Beni-Suef University, Egypt \\ ${ }^{3}$ HIKMA group, Pharmaceutical Company, Beni-Suef, Egypt
}

Submission: March 26, 2017; Published: March 31, 2017

*Corresponding author: MEM Hassouna, Department of Chemistry, Beni-Suef University, 62514, Egypt, Tel: +2 01223861504; Email: mhassouna47@hotmail.com; Mohamed.hassona@science.bsu.edu.eg

Abstract

A novel, specific, precise, simple, and accurate RP-HPLC method is developed and validated for simultaneous determination of Cefixime trihydrate (CFX) and Sodium benzoate (SDM) in powder for oral suspension (POS) dosage form. RP-HPLC method is performed on the Agilent Eclipse XDB C8 column ( $250 \mathrm{~mm} \mathrm{X} 4.6 \mathrm{~mm}, 5 \mu \mathrm{m}$ particle size, using buffer solution of $\mathrm{pH} 2.8$ containing 0.02M sodium dihydrogen phosphate: Acetonitrile $(50: 50 \mathrm{v} / \mathrm{v})$ as the mobile phase at a flow rate of $1.0 \mathrm{~mL} / \mathrm{min}$, injection volume $10 \mu \mathrm{L}$ and UV detection at $229 \mathrm{~nm}$. And the total run time was $7.0 \mathrm{~min}$. Linear relationships are obtained in the ranges of $5-200 \mu \mathrm{g} / \mathrm{mL}$ and $2-40 \mu \mathrm{g} / \mathrm{mL}$ for CFX and SDM, respectively, with significantly different $R_{t}$ values of 2.203 and 3.970 min for CFX and SDM with correlation coefficients $(r)>0.9999$, limits of detection of 1.36 and $0.21 \mu \mathrm{gmL}^{-1}$ and limits of quantitation was 4.14 and $0.64 \mu \mathrm{gmL}^{-1}$ for CFX and SDM, respectively. The obtained results for the suggested method were statistically compared with those obtained by official or the reported method for CFX and SDM, respectively using student's-t and F-ratio tests, showing that the methods are accurate and precise. This method is validated according to ICH guidelines and USP requirements for new methods, which include accuracy, precision, specificity, LOD, LOQ robustness, ruggedness, linearity and range. Hence this RP-HPLC method is suitable for quality control of raw materials and finished products. The accurate determination of low levels of both drugs is very important for the analysis of forensic problems.

Keywords: Cefixime trihydrate; Sodium benzoate; Validation; Forensic pharmacy; Powder for Oral Suspension dosage form; ICH; USP; HPLC

Abbreviations: CFX: Cefixime Trihydrate; SDM: Sodium Benzoate; POS: Powder for Oral Suspension; EPCI: Egyptian Pharmaceutical and Chemical Industry; BP: British Pharmacopeia; EP: European Pharmacopeia; USP: United States Pharmacopeia; TLC: thin layer chromatography; HPLC: high performance liquid chromatography; ICH: International Conference on Harmonization

\section{Introduction}

CFX; is chemically known as $(6 R, 7 R)-7-[[(Z)-2-(2-$ Aminothiazol-4-yl)-2-[(carboxymethoxy) imino] acetyl] amino]-3ethenyl-8-oxo-5-thia-1-azabicyclo [4.2.0] oct-2-ene-2-carboxylic acid trihydrate. It has a molecular formula of $\mathrm{C}_{16} \mathrm{H}_{15} \mathrm{~N}_{5} \mathrm{O}_{7} \mathrm{~S}_{2}, 3 \mathrm{H}_{2} \mathrm{O}$ and a molecular weight of 507.5 [1,2] (Figure 1A). CFX is a white or almost white, slightly hygroscopic powder. Slightly soluble in water, soluble in methanol, sparingly soluble in anhydrous ethanol, practically insoluble in ethyl acetate. A 5\% suspension in water has a pH of 2.6 to 4.1. Stored in airtight container to be protected from light $[1,2]$. CFX is bactericidal and is stable to hydrolysis by many beta-lactamases. Like other Cephalosporins, CFX possesses a mechanism of action similar to penicillins i.e. inhibition of transpeptidation process resulting in the formation of imperfect cell wall; osmotic drive from the outside isotonic environment of the host cell to the inside of the hypertonic bacterial cytoplasm and finally activation of the autolysin enzyme leading to the lysis of bacteria. Only 40 to $50 \%$ of an oral dose of CFX is absorbed from the gastrointestinal tract, whether taken before or after meals, although the rate of absorption may 
be decreased in the presence of food [3]. CFX is better absorbed from oral suspension than from tablets. CFX is generally classified as a third -generation Cephalosporin antibacterial and is given orally to treat infection due to susceptible Gram -positive and Gram-negative bacteria, including gonorrhea and infections of the respiratory and urinary tracts [3]. In spite of the significant progress in chemotherapy of bacterial infections, it was needed to reveal the mystery about the deaths of infants and children with known bacterial infections [4].<smiles>C=CC1=C(C(=O)O)N2C(=O)[C@H](NC(=O)/C(=N\OCC(=O)O)c3csc(N)n3)[C@H]2SC1</smiles>

(A)

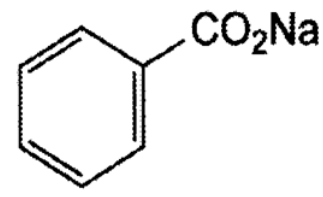

(B)

Figures 1A \& 1B: Chemical structures of (A) Cefixime trihydrate, (B) Sodium Benzoate.

In order to establish or confirm the cause of death of children in whom bacterial infections cases, it is very often questioned whether the therapy applied or medicine prescribed were correct and, indeed whether the prescribed medicine was administered at all. So the problem of establishing their presence in post-mortem material can form a problem for forensic medical work. Thus, the development of accurate and simple methods for the determination of traces of CFX besides the isolation and cleanup process by using solid phase extraction for fluoroquinolones and cephalosporins antibiotic drugs, contribute much for the analysis of forensic samples [5]. SDM; is chemically known as sodium benzenecarboxylate. It has a molecular formula of $\mathrm{C}_{7} \mathrm{H}_{5} \mathrm{NaO}_{2}$ and a molecular weight of 144.1 $[1,2]$ (Figure 1B). SDM is a white or almost white, crystalline or granular powder or flakes, slightly hygroscopic. Freely soluble in water, sparingly soluble in ethanol $(90$ per cent $V / V)[1,2]$. SDM is used primarily as antimicrobial preservative in cosmetics, foods, and pharmaceuticals. It used in concentrations of $0.02-0.5 \%$ in oral medicines, $0.5 \%$ in parenteral products, and $0.1-0.5 \%$ in cosmetics. The inhibitory concentration of sodium benzoate required in emulsion increases with oil content. SDM has also been used as a tablet lubricant at $2-5 \% \mathrm{w} / \mathrm{w}$ concentrations, providing rapid disintegration times [6]. SDM is mandatory in forensic toxicology laboratories to identify drug abuse; quantification in saliva is important additional information as this gives an indication about the level of abuse, where citric acid is used to stimulate the saliva production and sodium benzoate is used as preservative [7].

CFX is official in British Pharmacopeia (BP), European Pharmacopeia (EP) [1,2] and United States Pharmacopeia (USP) [8], both of them includes HPLC Method for its estimation. Literature review revealed that various analytical methods have been described for the determination of CFX including colorimetric and spectrophotometric [9-22], thin layer chromatography (TLC) [23-26], capillary electrophoresis [2729], high performance liquid chromatography (HPLC) [30-39] and electrochemical methods [40-43] have been developed for the estimation of CFX in pure or in dosage forms. SDM is official in BP, EP [1,2] and United States Pharmacopeia (USP) [8], which includes direct titration for estimation of SDM. A variety of methods have been developed for its determination including spectrophotometric $[44,45]$, thin layer chromatography (TLC) [46] and high performance liquid chromatography (HPLC) [4756]. The combination of these two drugs is not official in any pharmacopoeia. According to the best of our knowledge, no RPHPLC method is reported for the simultaneous determination of both CFX and SDM together in pure or dosage forms. The present study aims to develop a simple, sensitive, short retention time and accurate RP-HPLC method for the simultaneous determination of both CFX and SDM together in pure or dosage forms with high sensitivity, selectivity that are required to forensic pharmacy which is an application of the sciences of drugs to legal issues [57] and validate the developed methods according to ICH guidelines [57].

\section{Materials and methods}

\section{Apparatus}

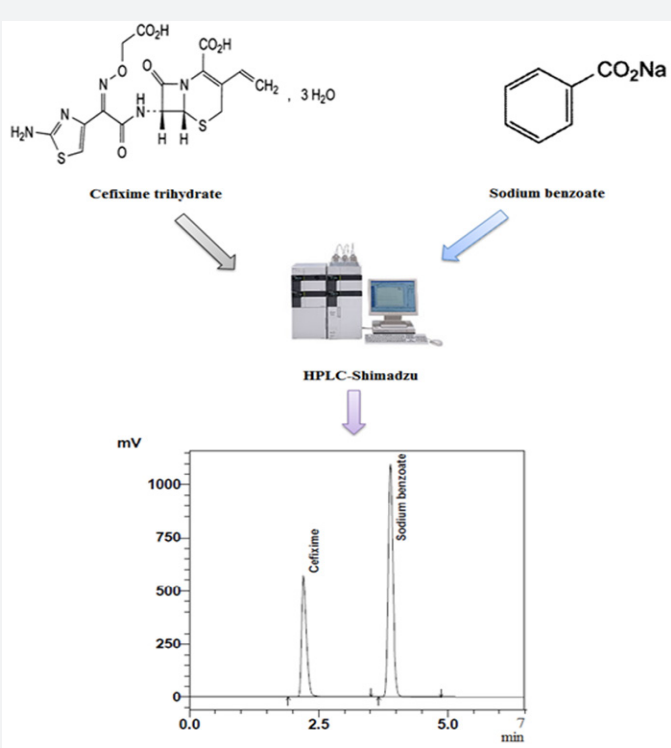

Figures 2: HPLC system (Shimadzu LC SPD 20 A) with a detector (dual wavelength), equipped with a binary pump, Autosampler, oven CTO-20A/20AC with temperature range (10$\left.85^{\circ} \mathrm{C}\right)$, LC Solution software. 
HPLC system (Shimadzu LC SPD 20 A) with a detector (dual wavelength), equipped with a binary pump, Autosampler, oven CTO-20A/20AC with temperature range $\left(10-85^{\circ} \mathrm{C}\right)$, LC Solution software (Figure 2).

\section{Pure samples}

Pure samples of CFX and SDM are kindly supplied by EPCI Pharmaceutical Company part of HIKMA group, Beni-Suef, Egypt with claimed purity of $99.97 \%$ and $99.90 \%$, respectively, according to Quality Control certificates of analysis.

\section{Pharmaceutical dosage form}

SUPRAX® $100 \mathrm{mg} / 5 \mathrm{~mL}$ POS (60mL) (Batch No. 2000) and SUPRAX® $100 \mathrm{mg} / 5 \mathrm{~mL}$ POS (30mL) (Batch No. 2002) are manufactured by the Egyptian Pharmaceutical and Chemical Industry (EPCI) Pharmaceutical Company part of HIKMA group, Beni-Suef, Egypt. Each $5 \mathrm{~mL}$ is claimed to contain $100 \mathrm{mg}$ of CFX and $2.5 \mathrm{mg}$ of SDM.

\section{Chemicals}

Acetonitrile, Methanol HPLC-grade, Sodium dihydrogen phosphate monohydrate analytical grade and distilled water are procured from (scharlau, Spain).

\section{Mobile phase preparation: Buffer: Acetonitrile (50:50)}

Sodium dihydrogen buffer is prepared by dissolving 2.76 gm of sodium dihydrogen phosphate monohydrate in $700 \mathrm{~mL}$ distilled water and sonicated to dissolve, adjust the $\mathrm{pH}$ to 2.8 by the addition of orthophosphoric acid solution. Make up to 1000 $\mathrm{mL}$ with distilled water, filter and degase mixtures of buffer and acetonitrile (50:50) through $0.45 \mu$ membrane filter under vacuum pump.

\section{Diluent: Methanol: Buffer (20:80)}

\section{HPLC chromatographic conditions}

Chromatographic separation is performed on column Agilent Eclipse XDB- C8 (250 X 4.6 mm i.d, $5 \mu \mathrm{m}$ particle size). Using a mobile phase mixture of sodium dihydrogen phosphate buffer and acetonitrile in the ratio of 50:50 \% v/v at ambient temperature, flow rate of $1.0 \mathrm{~mL} / \mathrm{min}$, UV detection is performed at $229 \mathrm{~nm}$, injection volume is $10 \mu \mathrm{L}$ and run time is $7.0 \mathrm{~min}$.

\section{Preparation of Standard and samples Solution}

A. Standard solutions preparation of Cefixime and Sodium benzoate: The stock standard solution $\left(1.6 \mathrm{mg} \mathrm{mL}^{-1}\right.$ of CFX and $0.04 \mathrm{mg} \mathrm{mL}^{-1}$ of SDM) is prepared by dissolving $160 \mathrm{mg}$ of CFX and $4 \mathrm{mg}$ of SDM in $70 \mathrm{~mL}$ of diluent and is sonicated to dissolve. Complete to the mark with the same diluent and mix well. Standard solution is prepared by transferring $5 \mathrm{~mL}$ of the standard stock solution to $50 \mathrm{~mL}$ volumetric flask of diluent to get a concentration of $0.16 \mathrm{mg} \mathrm{mL}^{-1}$ of CFX and $0.004 \mathrm{mg} \mathrm{mL}^{-1}$ of SDM. The obtained chromatogram is shown in Figure 3A.

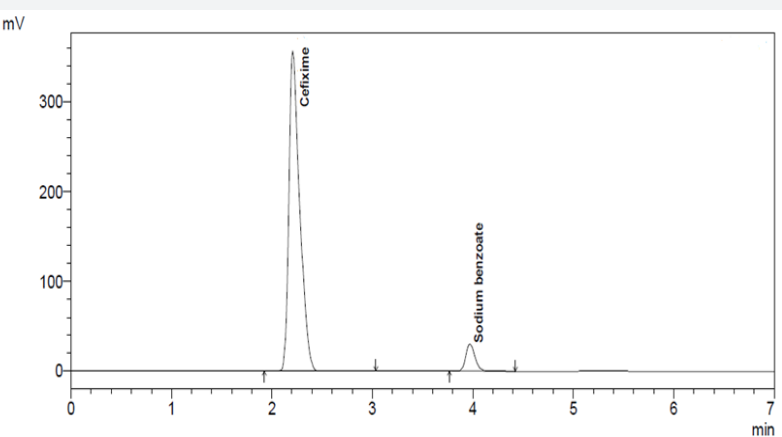

(A)

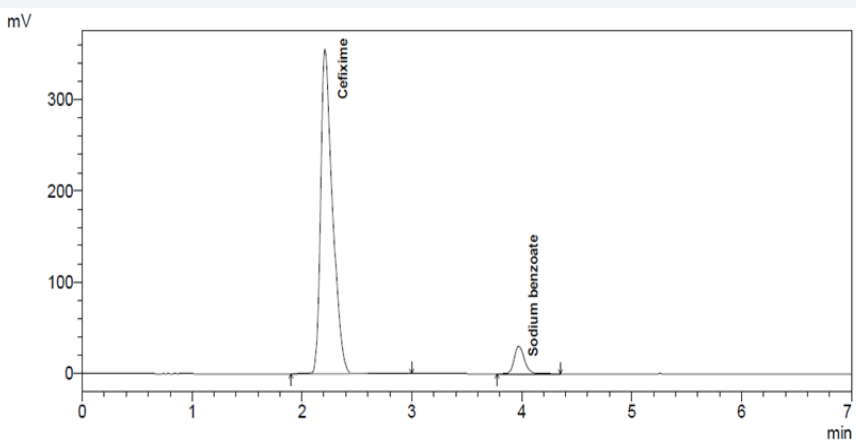

(C)

Figure 3A, 3B \& 3C: HPLC chromatogram of Assay for (A) standard solution of CFX/SDM, (B) sample of SUPRAX (60 mL) $100 \mathrm{mg} / 5 \mathrm{~mL}$ POS and (C) sample of SUPRAX (30 mL) $100 \mathrm{mg} / 5 \mathrm{~mL}$ POS dosage form. 
B. Authentic prepared mixture: Due to the low concentration of SDM in the dosage form, where the concentration of CFX is Forty-folds greater than SDM, so we prepared an equal concentration $\left(0.2 \mathrm{mg} \mathrm{mL}^{-1}\right)$ of each in the mixture to validate their simultaneous determination. The obtained chromatogram is shown in Figure 4.

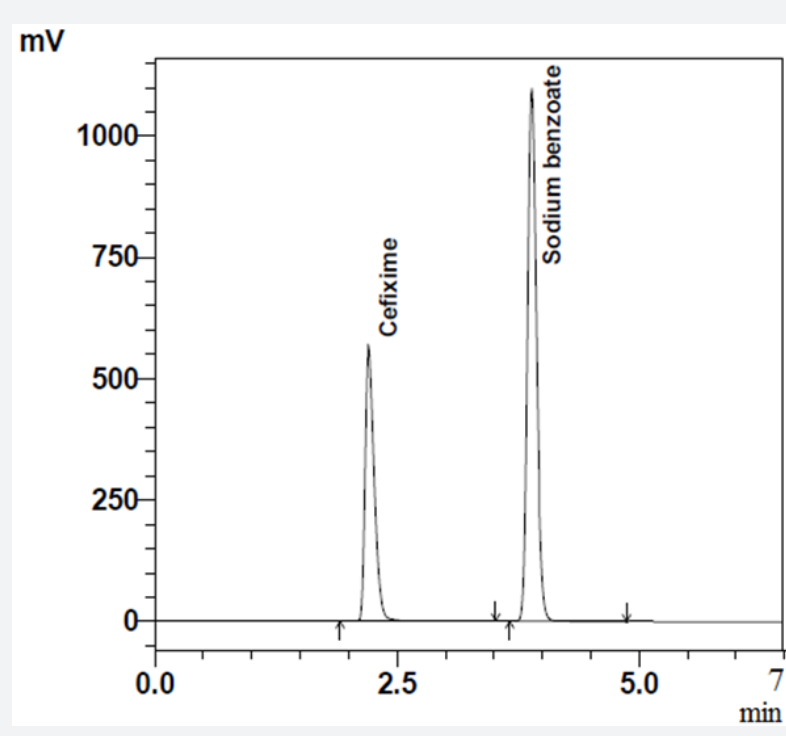

Figures 4: HPLC chromatogram of an authentic mixture of (200 $\mu \mathrm{g} / \mathrm{mL}$ ) of CFX and SDM, respectively.

\section{Application to pharmaceutical formulation (SUPRAX® $100 \mathrm{mg} / 5 \mathrm{~mL}$ POS $(60 \mathrm{~mL}) \&(30 \mathrm{~mL}))$}

Constitute Suprax as directed in the labeling. Transfer an accurately $2.0 \mathrm{~mL}$ of the oral suspension into a 250 -mL volumetric flask. Dilute with solvent to achieve a final concentration of $0.16 \mathrm{mg} \mathrm{mL}^{-1}$ for CFX and $0.004 \mathrm{mg} \mathrm{mL}^{-1}$ for SDM. The obtained chromatogram is shown in Figures 3B \& 3C. Also, the standard addition technique has been carried out to assess the validity of the method by spiking the pharmaceutical formulation with known amount of standard solution of CFX and SDM. The recovery of the added standards is then calculated after applying the proposed method.

\section{Construction of calibration curves}

Different concentrations of CFX and SDM equivalent to (5200) $\mu \mathrm{g} / \mathrm{mL}$ and (2-40) $\mu \mathrm{g} / \mathrm{mL}$ for CFX and SDM, respectively, are separately withdrawn from their respective stock standards into separate series of $100 \mathrm{~mL}$ volumetric flasks, and the volumes are made up to volume with the diluent. Duplicate $10 \mu \mathrm{L}$ injections are made for each concentration maintaining the flow rate at $1.0 \mathrm{~mL} / \mathrm{min}$ and the effluent is UV- scanned at $229 \mathrm{~nm}$. The chromatographic separation is performed following the procedure under chromatographic conditions. The chromatograms are recorded, peak areas of CFX and SDM are determined, the calibration curves relating the obtained integrated peak areas to the corresponding concentrations are constructed and the regression equations are performed.

\section{Results and Discussion}

The purpose of this work is to present simple, sensitive, accurate, precise and novel HPLC method for the simultaneous determination of binary mixture of the two drugs, viz., CFX and SDM in their pure form and in pharmaceutical formulation. Also, to achieve the concentration and recovery for laboratory prepared mixture and applying the standard addition technique for each method. Obtained chromatograms have significantly different $R_{t}$ values of 2.203 and 3.970 min for CFX and with correlation coefficients $(r)>0.9999$, limits of detection of 1.36 and $0.21 \mu \mathrm{g} \mathrm{mL} \mathrm{m}^{-1}$ and limits of quantitation of 4.14 and $0.64 \mu \mathrm{g}$ $\mathrm{mL}^{-1}$ for CFX and SDM, respectively. No occurrence of interfering peaks is reported.

\section{Methods development and optimization}

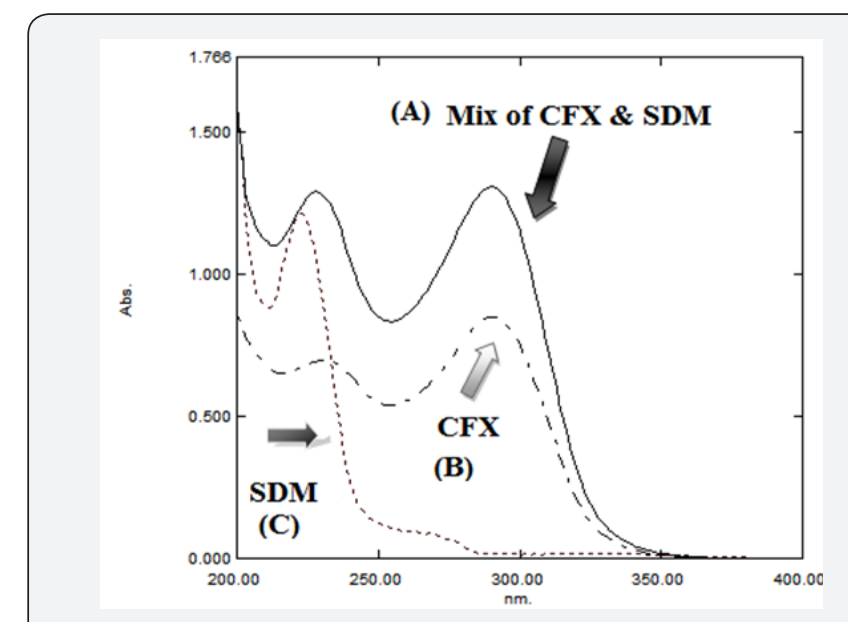

Figures 5: UV absorption spectra of (A) mix of CFX and SDM (B) CFX and (C) SDM using Methanol as a blank.

Different developing systems of different compositions and ratios are tried including: methanol: water (50:50, v/v), acetonitrile: water $(50: 50, \mathrm{v} / \mathrm{v})$ and potassium dihydrogen phosphate $\mathrm{pH}$ (4.5): ACN (50:50, v/v), under such conditions no peak is observed for SDM. On using a buffer mixture composed of sodium dihydrogen phosphate pH (2.8): ACN (50:50), good separation of both drugs has been achieved. Also, different flow rates are tried $(0.7,1.0,1.2$ and $1.5 \mathrm{~mL} / \mathrm{min})$, scanning wavelengths (200 $-400 \mathrm{~nm})$ are also tried for both drugs in pure form (Conc. of CFX $\equiv 50 \mu \mathrm{g} / \mathrm{mL}$ and SDM $\equiv 10 \mu \mathrm{g} / \mathrm{mL}$ ) and laboratory prepared mixture. The wavelength $229 \mathrm{~nm}$ gives the best suitable absorbance for both drugs (Figure 5). Preliminary studies involved trying C18, C8 reversed-phase columns, finally, the column Agilent Eclipse XDB- C8 (250 mm X 4.6 mm i.d., $5 \mu \mathrm{m}$ ) achieved the best resolution between both drugs and sharp peaks with good $R_{t}$ values without tailing of the separated bands and good theoretical plates.

\section{Validation of the analytical method}

The method was validated, in accordance with ICH guidelines (ICH Q2R1), for system suitability, precision, accuracy, linearity, specificity, ruggedness, robustness, LOD and LOQ. 


\section{Journal of Forensic Sciences \& Criminal Investigation}

I. Linearity and range: The linearity of the proposed methods is obtained in the concentration range $(5.0-200.0 \mu \mathrm{g} /$ $\mathrm{mL}$ ) for CFX and (2.0 $-40.0 \mu \mathrm{g} / \mathrm{mL}$ ) for SDM. Calibration curves are composed by plotting peak areas against the corresponding concentrations. The obtained coefficients of regression are 0.9999 for both CFX and SDM. Linearity results are shown in Table 1.
II. Repeatability: Repeatability of the method is evaluated by calculating the RSD of the peak areas of six replicate injections from the standard concentration $(160.0 \mu \mathrm{g} / \mathrm{mL})$ of CFX and $(4.0$ $\mu \mathrm{g} / \mathrm{mL}$ ) of SDM. Results are examined as \% RSD values of the concentrations of determined drugs. Low values of \% RSD (less than 2) indicate high precision of the method as shown in Table 1.

Table 1: Regression and validation parameters of the proposed HPLC method for determination of CFX and SDM.

\begin{tabular}{|c|c|c|}
\hline Parameter & CFX & SDM \\
\hline Linear range $(\mu \mathrm{g} / \mathrm{mL})$ & $5-200$ & 47222.2398 \\
\hline Slope & 16765.5576 & 1064.9510 \\
\hline Intercept & 547.2735 & 0.9999 \\
\hline Correlation coefficient & 0.9999 & 0.21 \\
\hline LOD $^{\mathrm{a}}(\mu \mathrm{g} / \mathrm{mL})$ & 1.36 & 0.64 \\
\hline LOQ $^{\mathrm{a}}(\mu \mathrm{g} / \mathrm{mL})$ & 4.14 & 0.161 \\
\hline Repeatability & 0.163 & 0.16 \\
\hline
\end{tabular}

a Limit of detection $(3.3 \times \sigma /$ Slope $)$ and limit of quantitation $(10 \times \sigma /$ Slope $)$.

${ }^{\mathrm{b}}$ Repeatability for $\mathrm{n} \geq 5$, RSD $\leq 2$.

III. Detection and quantitation limits: These approaches are based on the Standard Deviation of the Response and the Slope. A specific calibration curve should be studied using samples containing an analyte in the range of LOD and LOQ. The residual standard deviation of a regression line or the standard deviation of $y$-intercepts of regression lines may be used as the standard deviation. $\mathrm{LOD}=3.3 \times \sigma /$ slope and $\mathrm{LOQ}=10 \times \sigma /$ slope, where $\sigma=$ the standard deviation of the response, Table 1 .

IV. Accuracy and recovery: Accuracy of the proposed methods is calculated as the percentage recoveries of pure samples of the studied drugs. Accuracy is assessed using three different concentrations $(40,80 \& 160 \mu \mathrm{g} / \mathrm{mL})$ for CFX and $(5,10 \& 15 \mu \mathrm{g} / \mathrm{mL})$ for SDM within linearity range (i.e. three concentrations and three replicates). Concentrations are calculated from the corresponding regression equations. The mean \% recoveries for CFX and SDM are between $98.0 \%$ and 102 $\%$. These data are shown in Table 2. Accuracy is further assessed by applying the standard addition technique to SUPRAX® 100 $\mathrm{mg} / 5 \mathrm{~mL}$ POS $(60 \mathrm{~mL})$ \& $(30 \mathrm{~mL})$, where good recoveries are obtained revealing that there is no interference from excipients, Tables 3 \& 4 .

Table 2: Data of Accuracy for CFX and SDM.

\begin{tabular}{|c|c|c|c|c|c|c|c|}
\hline \multirow{2}{*}{$\begin{array}{l}\text { Cefixime Standard } \\
\qquad(\mu \mathrm{g} / \mathrm{mL})\end{array}$} & \multicolumn{3}{|c|}{ CFX } & \multirow{2}{*}{$\begin{array}{l}\text { Sodium Benzoate } \\
\text { Standard }(\mu \mathrm{g} / \mathrm{mL})\end{array}$} & \multicolumn{3}{|c|}{ SDM } \\
\hline & $\mu \mathrm{g} / \mathrm{mL}$ (Injected) & $\begin{array}{l}\mu g / m L \\
\text { (found) }\end{array}$ & Recovery\% & & $\mu \mathrm{g} / \mathrm{mL}($ Injected) & $\begin{array}{l}\mu g / m L \\
\text { (found) }\end{array}$ & Recovery\% \\
\hline \multirow[t]{3}{*}{40} & 40 & 39.48 & $98.70 \%$ & \multirow{3}{*}{5} & 5 & 5.07 & 101.43 \\
\hline & 40 & 39.39 & $98.48 \%$ & & 5 & 5.06 & 101.20 \\
\hline & 40 & 39.42 & $98.55 \%$ & & 5 & 5.06 & 101.16 \\
\hline \multirow[t]{3}{*}{80} & 80 & 78.71 & $98.38 \%$ & \multirow{3}{*}{10} & 10 & 10.14 & 101.43 \\
\hline & 80 & 78.77 & $98.47 \%$ & & 10 & 10.11 & 101.12 \\
\hline & 80 & 79.04 & $98.80 \%$ & & 10 & 10.12 & 101.18 \\
\hline \multirow[t]{3}{*}{160} & 160 & 158.88 & $99.30 \%$ & \multirow{3}{*}{15} & 15 & 14.97 & 99.79 \\
\hline & 160 & 157.69 & $98.56 \%$ & & 15 & 15.09 & 100.57 \\
\hline & 160 & 157.43 & 98.40 & & 15 & 15.07 & 100.50 \\
\hline Accuracy (Mean) & \multicolumn{3}{|c|}{98.62} & Accuracy (Mean) & \multicolumn{3}{|c|}{100.93} \\
\hline
\end{tabular}


Table 3: Determination of CFX and SDM in pharmaceutical formulation by the proposed HPLC method and application of standard addition technique.

\begin{tabular}{|c|c|c|c|c|}
\hline \multirow{2}{*}{ Pharmaceutical formulation } & \multicolumn{2}{|c|}{ Added $(\boldsymbol{\mu g} / \mathbf{m L})$} & \multicolumn{2}{c|}{ Recovery \% } \\
\cline { 2 - 5 } & CFX & SDM & 99.18 & 100.22 \\
\hline SUPRAX $100 \mathrm{mg} / 5 \mathrm{~mL}$ POS $(60 \mathrm{~mL})$ & 10 & 6 & 101.71 & 101.16 \\
\hline CFX, $100 \mathrm{mg}$ (claimed) & 20 & 26 & 98.39 & 100.13 \\
\hline SDM, $2.5 \mathrm{mg}$ (claimed) & 30 & & $99.76 \pm 1.74$ & $100.51 \pm 0.57$ \\
\hline Mean \pm RSD & & & \multicolumn{2}{c|}{ CFX } \\
\hline
\end{tabular}

Table 4: Determination of CFX and SDM in pharmaceutical formulation by the proposed HPLC method and application of standard addition technique.

\begin{tabular}{|c|c|c|c|c|}
\hline \multirow{2}{*}{ Pharmaceutical formulation } & \multicolumn{2}{|c|}{ Recovery \% } & \multicolumn{2}{|c|}{$\operatorname{Added}(\mu \mathrm{g} / \mathrm{mL})$} \\
\hline & CFX & SDM & CFX & SDM \\
\hline SUPRAX $100 \mathrm{mg} / 5 \mathrm{~mL}$ POS (30 mL) & 10 & 6 & 101.46 & 98.49 \\
\hline CFX, 100 mg (claimed) & 20 & 16 & 101.24 & 100.76 \\
\hline SDM, $2.5 \mathrm{mg}$ (claimed) & 30 & 26 & 100.26 & 100.20 \\
\hline Mean \pm RSD & & & $100.99 \pm 0.63$ & $99.82 \pm 1.19$ \\
\hline
\end{tabular}

V. Formulation assay: The validated method is applied for the determination of CFX and SDM in commercially available SUPRAX® $100 \mathrm{mg} / 5 \mathrm{~mL}$ POS $(60 \mathrm{~mL}) \&(30 \mathrm{~mL})$. The results of the assay undertaken yielded recoveries of $103.51 \%$ and 99.90\%, 99.93\% and $97.64 \%$ of the label claim for CFX and SDM, respectively. The results of the assay indicate that the method is selective for the analysis of SUPRAX® $100 \mathrm{mg} / 5 \mathrm{~mL}$ POS (60 $\mathrm{mL}) \&(30 \mathrm{~mL})$ without interference from the excipients used to formulate and produce these suspensions. The results are displayed in Tables $5 \& 6$. The obtained results for the analysis of CFX and SDM by the suggested methods are statistically compared with those obtained by applying the official HPLC [8] and reported HPLC [55] methods. The results showed no significant differences between the proposed and HPLC methods as presented in Table 7 .

Table 5: Assay results for the determination of CFX and SDM in pharmaceutical formulation by the proposed HPLC method.

\begin{tabular}{|c|c|c|c|c|c|c|}
\hline \multirow{2}{*}{ Pharmaceutical formulation } & \multicolumn{2}{|c|}{ Conc. $(\mu \mathrm{g} / \mathrm{mL})$} & \multicolumn{2}{|c|}{ Recovery \% } & \multicolumn{2}{|c|}{ limit \% } \\
\hline & CFX & SDM & CFX & SDM & CFX & SDM \\
\hline \multirow{2}{*}{ SUPRAX $100 \mathrm{mg} / 5 \mathrm{~mL}$ POS (60 mL) } & 100 & 2.5 & $103.35 \%$ & $99.33 \%$ & $(90-120)$ & $(70-120)$ \\
\hline & & & $103.36 \%$ & $99.90 \%$ & & \\
\hline \multirow{2}{*}{ CFX, 100 mg (claimed) } & & & $103.11 \%$ & $100.60 \%$ & & \\
\hline & & & $102.78 \%$ & $99.90 \%$ & & \\
\hline \multirow{2}{*}{ SDM, $2.5 \mathrm{mg}$ (claimed) } & & & $103.94 \%$ & $99.75 \%$ & & \\
\hline & & & $104.53 \%$ & $99.94 \%$ & & \\
\hline Mean \pm RSD & & & $103.51 \pm 0.61$ & $99.90 \pm 0.40$ & & \\
\hline
\end{tabular}

Table 6: Assay result for the determination of CFX and SDM in pharmaceutical formulation by the proposed HPLC method.

\begin{tabular}{|c|c|c|c|c|c|c|}
\hline \multirow{2}{*}{ Pharmaceutical formulation } & \multicolumn{2}{|c|}{ Conc. $(\mu \mathrm{g} / \mathrm{mL})$} & \multicolumn{2}{|c|}{ Recovery \% } & \multicolumn{2}{|c|}{ limit \% } \\
\hline & CFX & SDM & CFX & SDM & CFX & SDM \\
\hline \multirow{2}{*}{ SUPRAX $100 \mathrm{mg} / 5 \mathrm{~mL}$ POS (30 mL) } & 100 & 2.5 & $100.54 \%$ & $96.04 \%$ & $(90-120)$ & $(70-120)$ \\
\hline & & & $99.35 \%$ & $96.45 \%$ & & \\
\hline \multirow{2}{*}{ CFX, 100 mg (claimed) } & & & $99.14 \%$ & $98.25 \%$ & & \\
\hline & & & $100.13 \%$ & $99.09 \%$ & & \\
\hline \multirow{2}{*}{ SDM, $2.5 \mathrm{mg}$ (claimed) } & & & $99.76 \%$ & $98.07 \%$ & & \\
\hline & & & $100.71 \%$ & $97.97 \%$ & & \\
\hline Mean \pm RSD & & & $99.93 \pm 0.63$ & $97.64 \pm 1.19$ & & \\
\hline
\end{tabular}


Table 7: Statistical comparison between the results obtained by applying the proposed methods and those obtained by the official and the reported methods for the analysis of the pure form of CFX and SDM in their pharmaceutical formulation.

\begin{tabular}{|c|c|c|c|c|}
\hline \multirow{2}{*}{ Method } & Official Method $^{\mathrm{a}}[\mathbf{8}]$ & proposed Method & proposed Method & Reported Method $^{\mathbf{b}}[\mathbf{5 5}]$ \\
\cline { 2 - 5 } & CFX & CFX & SDM & 99.90 \\
\hline Mean & 103.46 & 103.51 & 0.409 & 0.379 \\
\hline SD & 0.677 & 0.627 & 0.167 & 0.144 \\
\hline Variance & 0.458 & 0.393 & 6 & 5 \\
\hline N & 6 & 6 & 0.996 & - \\
\hline t-test* $^{*}$ & - & 0.119 & 1.164 & - \\
\hline F-value* & - & 1.166 & & \\
\hline
\end{tabular}

*the values in parenthesis are corresponding to the theoretical values of $t$ and $F(p=0.05)$.

afficial method: RP-HPLC determination of CFX using Mobile phase: (Acetonitrile and Solution A) (1:3) L1 column $(4 \mu \mathrm{m}, 12.5 \mathrm{~cm} \times 4.6 \mathrm{~mm}$ I.D.) Solution A: $25 \mathrm{~mL}$ of $0.4 \mathrm{M}$ tetrabutylammonium hydroxide solution diluted with water to $1000 \mathrm{~mL}$, and adjusted with $1.5 \mathrm{M}$ phosphoric acid to a $\mathrm{pH}$ of 6.5 , Flow rate: Adjusted so that the retention time of cefixime is about $10 \mathrm{~min}$ at $254 \mathrm{~nm}$ and Injection volume: $10 \mu \mathrm{L}$.

${ }^{b}$ Reported method: Effective chromatographic separation of betamethasone and sodium benzoate was achieved using Novapack-C18 $(150 \times 3.9 \mathrm{~mm}, 4 \mu \mathrm{m})$ column with gradient elution of the mobile phase composed of $50 \mathrm{mM}$ monobasic potassium phosphate buffer ( $\mathrm{pH}$ 2.9) and acetonitrile. The elution was a three-step gradient elution program with $25 \%$ acetonitrile and $75 \%$ buffer at 0 min further acetonitrile concentration changed linearly to $45 \%$ up to $25 \mathrm{~min}$, followed by changing acetonitrile to $25 \%$ up to $35 \mathrm{~min}$.

VI. Intermediate precision (ruggedness): Intermediate precision expresses within-laboratories variations: different days, different analysts, different equipments, etc. Good results are obtained and presented in Table 8.

Table 8: Ruggedness of the method.

\begin{tabular}{|c|c|c|}
\hline Parameter(\%RSD) & CFX & SDM \\
\hline Intraday & 0.135 & 0.131 \\
\hline Interday & 1.097 & 0.553 \\
\hline Analyst to Analyst & 0.138 & 0.377 \\
\hline Column to Column & 0.739 & 0.332 \\
\hline
\end{tabular}

VII. Robustness: The robustness of the proposed methods is evaluated within the development phase where the different factors affecting the method are studied to obtain the optimum parameters for complete separation. Robustness of the method is studied by deliberately varying parameters like flow rate $( \pm$ $0.1 \mathrm{~mL} / \mathrm{min}$ ), studying the effect of changing the mobile phase $\mathrm{pH}$ by $( \pm 0.2)$, acetonitrile composition $( \pm 5 \%)$ and column temperature which is changed between $\left(30^{\circ} \& 25^{\circ}\right)$. The low values of the $\%$ RSD, as given in Table 9 , indicate the robustness of the proposed methods.

Table 9: Robustness of the method.

\begin{tabular}{|c|c|c|}
\hline Parameter(\%RSD) & CFX & SDM \\
\hline Flow rate change $( \pm 0.1 \mathrm{~mL} / \mathrm{min})$ & 1.770 & 0.567 \\
\hline pH change of mobile phase $( \pm 0.2)$ & 1.391 & 0.856 \\
\hline Wave length change $(229 \mathrm{~nm}, 254 \mathrm{~nm})$ & 0.770 & 0.780 \\
\hline Column temperature change $\left(30,25^{\circ} \mathrm{C}\right)$ & 0.735 & 0.764 \\
\hline
\end{tabular}

VIII. System suitability: System suitability testing is an integral part of many analytical procedures. The tests are based on the concept that the equipment, electronics, analytical operations and samples to be analyzed constitute an integral system that can be evaluated as such. System suitability is checked by calculating tailing factor (T), column efficiency $(\mathrm{N})$, resolution $\left(R_{s}\right)$ factors. All calculated parameters are within the acceptable limits indicating good selectivity of the methods and ensuring system performance, (Table 10).

Table 10: System suitability testing parameters of the developed method

\begin{tabular}{|c|c|c|c|}
\hline \multirow{2}{*}{ Item } & \multicolumn{2}{|c|}{ Obtained Value } & \multirow{2}{*}{$\begin{array}{c}\text { Reference } \\
\text { values }\end{array}$} \\
\cline { 2 - 3 } & CFX & SDM & \\
\hline Tailing factor & 1.600 & 1.265 & $\mathrm{~T} \leq 2$ \\
\hline Resolution & - & 9.029 & $\mathrm{R}_{\mathrm{s}}>2$ \\
\hline Selectivity & - & 3.257 & $\mathrm{k}^{\prime}>2$ \\
\hline Injection precision & 0.163 & 0.161 & $\mathrm{RSD} \leq 1 \%$ \\
\hline Retention time (R) & 0.143 & 0.092 & $\mathrm{RSD} \leq 1 \%$ \\
\hline $\begin{array}{c}\text { Number of } \\
\text { theoretical plates(N) }\end{array}$ & 7750.661 & 7805.494 & $\mathrm{~N}>2000$ \\
\hline
\end{tabular}

IX. Stability of analytical solution: To demonstrate the stability of the standard solution during analysis, the solution is analyzed over a period of $24 \mathrm{~h}$ at room temperature and refrigerator. The results showed that for all solutions, the retention times and peak areas of CFX and SDM remained 
almost unchanged $(\mathrm{RSD}<2.0 \%)$ indicating that no significant degradation occurred within this period, i.e. both solutions are stable for at least $24 \mathrm{~h}$, which is sufficient to complete the whole analytical process. These results are displayed in Table 11.

Table 11: Result of stability of analytical solution.

\begin{tabular}{|c|c|c|}
\hline Condition & CFX & SDM \\
\hline Fridge $\left(2-8^{\circ} \mathrm{C}\right)$ & $100.22 \%$ & $98.53 \%$ \\
\hline Room temperature $\left(25^{\circ} \mathrm{C}\right)$ & $100.10 \%$ & $98.44 \%$ \\
\hline
\end{tabular}

X. Specificity: Specificity is tested against standard compounds and against potential interferences in the presence of placebo. No interference is detected at the retention times of CFX and SDM in placebo solution.

\section{Conclusion}

The proposed RP-HPLC method for simultaneous estimation of CFX and SDM in their dosage form is novel, precise, specific, highly accurate and less time consuming for analysis, low cost and rapid. The results of stress testing undertaken according to the International Conference on Harmonization (ICH) guidelines reveal that the method is selective. Based on the above results, the analytical method is valid, fit for use and can be used for regular routine analysis, stability study and forensic sciences \& criminal investigation.

\section{Acknowledgement}

The authors are thankful to the Publishers of the Journal of Forensic Sciences \& Criminal Investigation for the publication gift provided.

\section{References}

1. British Pharmacopoeia (2017) Stationary Office, Medicines and Healthcare Products Regulatory Agency. Volume II, UK.

2. European Pharmacopeia (2014) ( $8^{\text {th }}$ edn).

3. Sweetman SC (2011) Martindale: The Complete Drug Reference. (37 ${ }^{\text {th }}$ edn), The Pharmaceutical Press, UK.

4. Ewa Pufal, Marzena Sykutera, Karol Sliwka (2000) Determination of Cephalosporin Antibiotics in Post-Mortem Material. XLI: 37-51.

5. Mishra V, Sharma J, Shukla S (2008) Study for The Development of Isolation and Clean Up Process by Using Solid Phase Extraction (SPE) For Fluoroquinolones and Cephalosporins Antibiotic Drugs from Forensic Samples. The Internet Journal of Forensic Science 3(2).

6. Rowe RC, Sheskey PJ, Cook WG, Fenton ME (2012) Handbook of Pharmaceutical Excipients ( $7^{\text {th }}$ edn). Pharmaceutical Press, UK.

7. Steen Honoré Hansen, Stig Pedersen-Bjergaard (2015) Bioanalysis of Pharmaceuticals: Sample Preparation, Separation Techniques and Mass Spectrometry. 978-1-118-71681-6, pp.257.

8. The United States Pharmacopoeia (2015) NF 33, The United States Pharmacopoeia Convention Inc, ( $38^{\text {th }}$ Revision), USA.

9. V Shah, H Raj (2012) Development and validation of derivative spectroscopic method for simultaneous estimation of cefixime trihydrate and azithromycin dihydrate in combined dosage. International Journal of Pharma and Bio Sciences 3(3): 14-25.
10. SutarShubhangiV, Sancheti Harshal, PatilSS (2013) Spectrophotometric method for cefixime trihydrate by using hydrotropic agent. International Science Press (India) 6(2): 80-85.

11. Maheshwari RK, Kinariwala M, Saxena M, Gahlot M, Chaki R, et al. (2008) Spectrophotometric analysis of cefixime trihydrate tablets using metformin hydrochloride as hydrotropic solubilizing agent. Asian Journal of Chemistry 20(8): 6047-6050.

12. Ethiraj Thiruvengadam, Revathi Ramadoss, M Amudha (2012) Sensitive spectroscopic method for content analysis of cefixime in solid dosage form using hydrotropy phenomenon. Chronicles of Young Scientists 3(4): 299-303.

13. SNH Azmi, B Iqbal, JK Al Mamari, KA Al Hattali, WN Al Hadhrami (2014) Method Development and validation for the determination of cefixime in pure and commercial dosage forms by specrophotometry. Int J Chem Molec Nucl Mat Metallurg Eng 8(6): 595-601.

14. Ashok Kumar, Lalit Kishore, Anroop Nair, Navpreet Kaur (2011) Kinetic spectrophotometric method for the estimation of cefixime in pharmaceutical formulations, Der Pharma Chemica 3(4): 279-291.

15. Patel SA, Patel JV (2013) Spectrophotometric method for simultaneous estimation of cefixime trihydrate and linezolid in tablet dosage form. International Research Journal of Pharmacy 4(1): 161-164.

16. SS Pekamwar, TM Kalyankar, BV Tambe, SJ Wadher (2015) Validated UV-Visible spectrophotometric method for simultaneous estimation of cefixime and moxifloxacin in pharmaceutical dosage form. J Appl Pharm Sci 5(01): 037-041.

17. Mahesh Attimarad, Bander E Al-Dhubiab, Ibrahim A Alhaider, Anroop B Nair, Harsha N Sree (2012) Simultaneous determination of moxifloxacin and cefixime by first and ratio first derivative ultraviolet spectrophotometry. Chem Cent J 6: 105.

18. Md Ahasan Ullah Nayon, Jeb-Un Nesa, Md Nasir Uddin, Md Shah Amran, Umme Bushra (2013) Development and validation of UV, Spectrometric Method for the Determination of Cefixime trihydrate in Bulk and Pharmaceutical Formulation. Asian J Biomed Pharm Sci 3(22): 1-5.

19. Anees MI, Baig MS, Tathe A (2015) Determination of cefixime and moxifloxacin in pharmaceutical dosage form by simultaneous equation and area under curve UV-spectrophotometric method. World Journal of Pharmacy and Pharmaceutical Sciences 4(3): 1172-1179.

20. Ramadan AA, Mandil H, Dahhan M (2013) UV-VIS Spectrophotometric study for determination of cefixime in pure form and in pharmaceuticals through complexation with $\mathrm{Cu}(\mathrm{II})$ using acetate- $\mathrm{NaOH}$ buffer in water: methanol. International Journal of Pharmacy and Pharmaceutical Sciences 5: 428-433.

21. Shreya R Shah, Prasanna Pradhan, Suddhasattya Dey (2013) Quantitative estimation of cefixime and moxifloxacin in pharmaceutical preparation by UV spectrophotometric method. Int J Pharm Tech Res 5(1): 198-204.

22. Kumar R, Singh P, Singh H (2011) Develoment of colorimetric method for the analysis of pharmaceutical formulation containing both ofloxacin and cefixime. International Journal of Pharmacy and Pharmaceutical Sciences 3(2): 178-179.

23. Khandagle KS, Gandhi SV, Deshpande PB, Kale AN, Deshmukh PR (2010) High Performance Thin Layer Chromatographic determination of Cefixime and Ofloxacin in combined tablet dosage form. J Chem Pharm Res 2(5): 92-96.

24. Deshpande MM, Kasture VS, Gosavi SA (2010) Application of HPLC and HPTLC for the Simultaneous Determination of Cefixime Trihydrate and Ambroxol Hydrochloride in Pharmaceutical Dosage Form. Eurasian J Anal Chem 5(3): 227-238.

25. Dhoka MV, Gawande VT, Joshi PP (2013) Validated HPTLC Method 
for Determination of Cefixime Trihydrate and Erdosteine in Bulk and combined Pharmaceutical Dosage Form. Eurasian J Anal Chem 8(3): 99-106.

26. Rao J, Sethy K, Yadav S (2011) Validated HPTLC Method for Simultaneous Quantitation of Cifixime and Ofloxacin in Bulk Drug and in Pharmaceutical Formulation. Pharmacie Globale (IJCP) 4(5): 1-5.

27. Honda S, Taga A, Kakehi K, Koda S, Okamoto Y (1992) Determination of cefixime and its metabolites by high-performance capillary electrophoresis. J Chromatogr 590(2): 364-368.

28. Jain R, Gupta VK, Jadon N, Radhapyari K (2010) Voltammetric determination of cefixime in pharmaceuticals and biological Fluids. Anal Biochem 407(1): 79-88.

29. Ahmed O Alnajjar (2013) Simultaneous determination of ofloxacin and cifixime in tablet formulation using capillary electrophoresis. J Liq Chromatogr \& Related Technol 36: 36-41.

30. Somnath D Bhingea, Sharangouda M Malipatil (2015) Development and validation of stability indicating method for simultaneous estimation of cefixime and dicloxacillin using RP-HPLC method. Journal of Taibah University for Science 10(5): 734-744.

31. Elsadig HK Adam, Ahmed EM Saeed, Izzeldin E Barakat (2012) Development and validation of a high-performance liquid chromatography method for determination of cefixime trihydrate and its degradated products formed under stress condition of UV light. IJPSR 3(2): 469-473.

32. Saikrishna K, Akula G, Pandey VP, Sreedevi K, Bhupathi S, Banda SR (2010) Validation of reversed-phase HPLC method for the estimation of cefixime in cefixime oral suspension. IJPT 2(2): 385-395.

33. Kapil S Khandagle, Santosh V Gandhi, Padmanbh B Deshpande, Nilesh V Gaikwad (2011) A simple and sensitive RPHPLC method for simultaneous estimation of cefixime and ofloxacin in combined tablet dosage form. Int J Pharm Pharm Sci 3(1): 46-48.

34. Hariprasad T, Gurumoorthy P, Ali JN (2014) Analytical Method Development and Validation of Cefixime Oral Suspension by RP-HPLC as Per ICH/USP Guidelines. IJIPBART 1(1): 47-58.

35. G Rathinavel, PB Mukherjee, J Valarmathy, L Samueljoshua, M Ganesh, et al. (2008) A validated RP-HPLC Method for Simultaneous Estimation of Cefixime and Cloxacillin in Tablets. E-Journal of Chemistry 5(3): 648-651.

36. Falkowski AJ, Look ZM, Noguchi H, Silber BM (1987) Determination of cefixime in biological samples by reversed-phase high performance liquid chromatography. J Chromatogr 422: 145-152.

37. Rolando González-Hernández, Lauro Nuevas-Paz, Laritza Soto-Mulet, Miguel López-López, Joseph Hoogmartens (2001) Reversed phase high performance liquid chromatographic determination of cefixime in bulk drugs. J. Liq Chrom \& Rel Technol 24(15): 2315-2324.

38. MengF, Chen X,ZengY,Zhong D (2005) Sensitiveliquid chromatographytandem mass spectrometry method for the determination of cefixime in human plasma: Application to a pharmacokinetic study. J Chromatogr B 819(2): 277-282.

39. Talebpour Z, Pourabdollahi H, Rafati H, Abdollahpour A, Bashour Y, et al. (2013) Determination of Cefixime by a Validated Stability-Indicating HPLC Method and Identification of its Related Substances by LC-MS/ MS Studies. Sci Pharm 81(2): 493-503.

40. Golcu A, Dogan B, Ozkan SA (2005) Anodic voltammetric behavior and determination of cefixime in pharmaceutical dosage forms and biological fluids. Talanta 67(4): 703-712.

41. Afkhami A, Felehgari FS, Madrakian T (2013) Gold nanoparticles modified carbon paste electrode as an efficient electrochemical sensor for rapid and sensitive determination of cefixime in urine and pharmaceutical samples. Electrochimica Acta 103(30): 125-133.
42. M Asadollahi-Babolia, A Mani-Varnosfaderani (2014) Rapid and simultaneous determination of tetracycline and cefixime antibiotics by means of gold nanoparticles-screen printed gold electrode and chemometrics tools. Measurement 47: 145-149.

43. Reddy TM, Sreedhar M, Reddy S (2003) Voltammetric behavior of Cefixime and Cefpodoxime Proxetil and determination in pharmaceutical formulations and urine. J Pharm Biomed Anal 31(4): 811-818.

44. K Venkata Sowmya, K Ravishankar, D Peer Basha, GVN Kiranmayi (2011) Estimation of caffeine and sodium benzoate in caffeine and sodium benzoate injection by isoabsorption method. IJPCBS 1(1): 2631.

45. Mohsen Kompany-Zareh, Siavash Mirzaei (2004) Spectrophotometric resolution of ternary mixtures of pseudoephedrine hydrochloride, dextromethorphan hydrobromide, and sodium benzoate in syrups using wavelength selection by net analyte signals calculated with hybrid linear analysis. Anal Chim Acta 526(1): 83-94.

46. G Popović, M Čakar, D Agbaba (2007) Simultaneous Determination of Loratadine and Preservatives in Syrups by Thin-Layer Chromatography, Acta Chromatographica 19: 161-169.

47. Gören AC, Bilsel G, Simsek A, Bilsel M, Akçadag` F, et al. (2015) HPLC and LC-MS/MS methods for determination of sodium benzoate and potassium sorbate in food and beverages: Performances of local accredited laboratories via proficiency tests in Turkey. Food Chemistry 175: 273-279.

48. Bürge Așçı, Şule Dinç Zor, Özlem Aksu Dönmez (2016) Development and Validation of HPLC Method for the Simultaneous Determination of Five Food Additives and Caffeine in Soft Drinks. International Journal of Analytical Chemistry: 679-1687.

49. Małgorzata Grembecka, Piotr Baran, Agata Błażewicz, Zbigniew Fijałek, Piotr Szefer (2014) Simultaneous determination of aspartame, acesulfame-K, saccharin, citric acid and sodium benzoate in various food products using HPLC-CAD-UV/DAD. European Food Research and Technology 238(3): 357-365.

50. Can NO, Arli G, Lafci Y (2011) A novel RP-HPLC method for simultaneous determination of potassium sorbate and sodium benzoate in soft drinks using C18-bonded monolithic silica column. J Sep Sci 34(1617): 2214-2222.

51. Bahremand N, Eskandari S (2013) Determination of Potassium Sorbate and Sodium Benzoate in "Doogh" by HPLC and Comparison with Spectrophotometry. International Journal of Bio-Inorganic Hybrid NanoMaterials 2(3): 429-435.

52. Marjan Mahboubifar, Zahra Sobhani, Gholamreza Dehghanzadeh, Katayoun Javidnia (2011) A Comparison between UV Spectrophotometer and High-performance Liquid Chromatography Method for the Analysis of Sodium Benzoate and Potassium Sorbate in Food Products. Food Analytical Methods 4: 150-154.

53. Pylypiw HM Jr, Grether MT (2000) Rapid high-performance liquid chromatography method for the analysis of sodium benzoate and potassium sorbate in foods. J Chromatogr A 883(1-2): 299-304.

54.Vilas Khade, Sunil Mirgane (2014) High-performance liquid chromatography method for the analysis of sodium benzoate. Int J Sci \& Eng Res 5(10): 1382-1384.

55. Ali MB, Attia M, Bellili N, Fattouch S (2016) Development and Validation of a RP-HPLC Method for Simultaneous Determination of Betamethasone and Sodium Benzoate in Oral Liquid Pharmaceutical Formulation. Indian Journal of Pharmaceutical Sciences 78(3): 402408.

56. Esfandiar Z, Badiey M, Mahmoodian P, Sarhangpour R, Yazdani E, et al. (2013) Simultaneous Determination of Sodium Benzoate, Potassium Sorbate and Natamycin Content in Iranian Yoghurt Drink (Doogh) and 
the Associated Risk of Their Intake through Doogh Consumption. Iran J Public Health 42(8): 915-920.

57. Anderson PD (2012) The broad field of forensic pharmacy. J Pharm Pract 25(1): 7-12
58. ICH Q2 (R1) (2005) Validation of Analytical Procedures: Text and Methodology. ICH Harmonized Tripartite Guideline.

\section{Your next submission with Juniper Publishers will reach you the below assets}

- Quality Editorial service

- Swift Peer Review

- Reprints availability

- E-prints Service

- Manuscript Podcast for convenient understanding

- Global attainment for your research

- Manuscript accessibility in different formats

( Pdf, E-pub, Full Text, Audio)

- Unceasing customer service

Track the below URL for one-step submission https://juniperpublishers.com/online-submission.php 